\title{
ADDITIVE MANUFACTURING IN ASSISTING PLANNING OF PROTOTYPING AND CLOSED - DIE FORGING
}

\author{
Stefan SzczePanik, Piotr NikieL ${ }^{*}$ \\ AGH University of Science and Technology, al. Mickiewicza 30, 30-059 Krakow, Poland \\ *Corresponding author: pnikiel@metal.agh.edu.pl
}

\begin{abstract}
The steps in the current additive manufacturing processing sequence are: conceptualization and $\mathrm{CAD}$, conversion to STL, transfer and manipulation of STL file on an AM machine, machine setup, prototyping (additive manufacturing) of part, removal from machine and clean up, post-processing of the part. Modifications can be then made to satisfy the criteria of shape, stress and strain state and temperature distribution during processing. An example of this procedure is presented for a cup holder printed in 2 polymers. Modification to this procedure for metal printing is now presented: initially printing a polymer prototype. The methodology of planning the prototyping process and of closed die forging technology by applying 3D printing are described. For a con rod: preform, die and the forging models, based on CAD documentation and STL file, were initially $3 \mathrm{D}$ printed from a polymer in processing steps. Optimization was carried out prior to the expensive metal printing. It is shown that to optimize shape of the manufactured part, simulation is a key step of planning prototyping and forging technology.
\end{abstract}

Key words: Prototyping, Closed-die forging, FEM simulation, Additive manufacturing, Polymer printing

\section{INTRODUCTION}

Product development processes, which involve Prototyping/Additive Manufacturing machines and operators, have been expertly reviewed by Gibson et al. (2010), who reported that the eight key steps in the process sequence are: conceptualization and CAD, conversion to STL, transfer and manipulation of STL file on AM machine, machine setup, build, part removal and cleanup, post-processing of part, application. The Authors of (Gibson et al., 2010) added also that, with respect to production of polymer parts, most steps can be generalized to metal systems.

Some of the advantages of Additive Manufacturing (AM):

- rapid prototyping,

- unique geometries,

- custom manufacturing,

- unique surface features,

- reducing production operation steps,
- cost-saving practices.

Conventional manufacturing cannot be ignored completely since it is still the core to how majority of products is manufactured. Conventional technologies, such as die forging, can integrate with AM processes. Application of additive manufacturing to die forging has been described e.g. by Schwam and Silwal (2017) and Hirschvogel Tech Solutions (2018), who reported satisfactory mechanical properties of AM parts. Comparison of manufacturing costs of AM and closed-die forging (Schwam \& Silwal, 2017) is shown in figure 1.

In this paper additive manufacturing of a polymer cup holder and production of a polymer prototype for metal production and closed-die forging of a con rod are presented. 


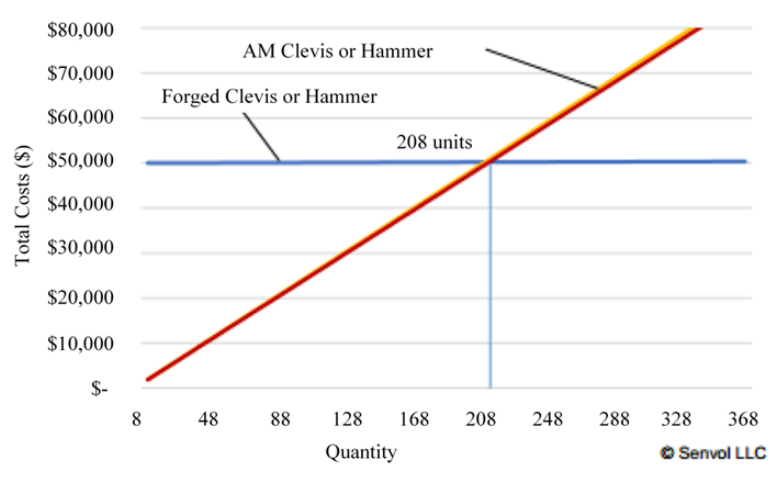

Fig. 1. Scheme of the 3 stages stepped $A A D$ process and the calibration stage.

\section{ADDITIVE MANUFACTURING OF POLYMER CUP HOLDER}

Process chain for drink holder prototyping, involving initial 3D polymer printing of a model is shown on figure 2 .

Stages of designing a drink holder are following: Step 1. A technical drawing of the holder.

Step 2. 3D in creaction of holder in CAD models for FEM strength simulation and optimisation of of the shape using Simufact Forming program.

Step 3. A conversion to STL files 3D model of the holder.

Step 4. Polymer printing of the holder and critical comparison of resultant polymer product with dimensional specifications.

Step 5. (if required) Modification of model, and repeat Steps 4 and 5.
Results of modelling are described below.

Step 1. A technical drawing of the holder and its components is shown in figure 3 .

Step 2. 3D creation CAD model of holder in Solid Works Xpress for FEM simulation.

The simulation was for 2 kilograms loading using 2 materials: ABS and nylon. The relevant properties of the materials are: $39 \mathrm{MPa}$ yield stress, $40 \mathrm{MPa}$ tensile strength, $2 \mathrm{GPa}$ Young's modulus, 0.39 Poisson ratio, $1.07 \mathrm{~g} / \mathrm{cm} 3$ density for the $\mathrm{ABS}$, and $140 \mathrm{MPa}$ yield stress, $143 \mathrm{MPa}$ tensile strength, $8.3 \mathrm{GPa}$ Young's modulus, 0.28 Poisson ratio, $1.4 \mathrm{~g} / \mathrm{cm} 3$ density for the nylon. The boundary condition for the simulations were Poisson ratio and Young's modulus.

Figure 4 shows the 3D model before and after loading to calculate equivalent stress under load $20 \mathrm{~N}$ in the model.

The casing and bottom plate were to be of the ABS and the connector of the nylon. The $20 \mathrm{MPa}$ value of calculated equivalent stresses in the casing and the bottom plate are smaller than $39 \mathrm{MPa}$ yield stress for the ABS and in the connector up to $60 \mathrm{MPa}$, smaller the $139 \mathrm{MPa}$ yield stress for the nylon.

Step 3. Conversion to STL files 3D model of the holder

Based on CAD code, the converted models in STL code were prepared (figure 5) to printing 3D models in stages.

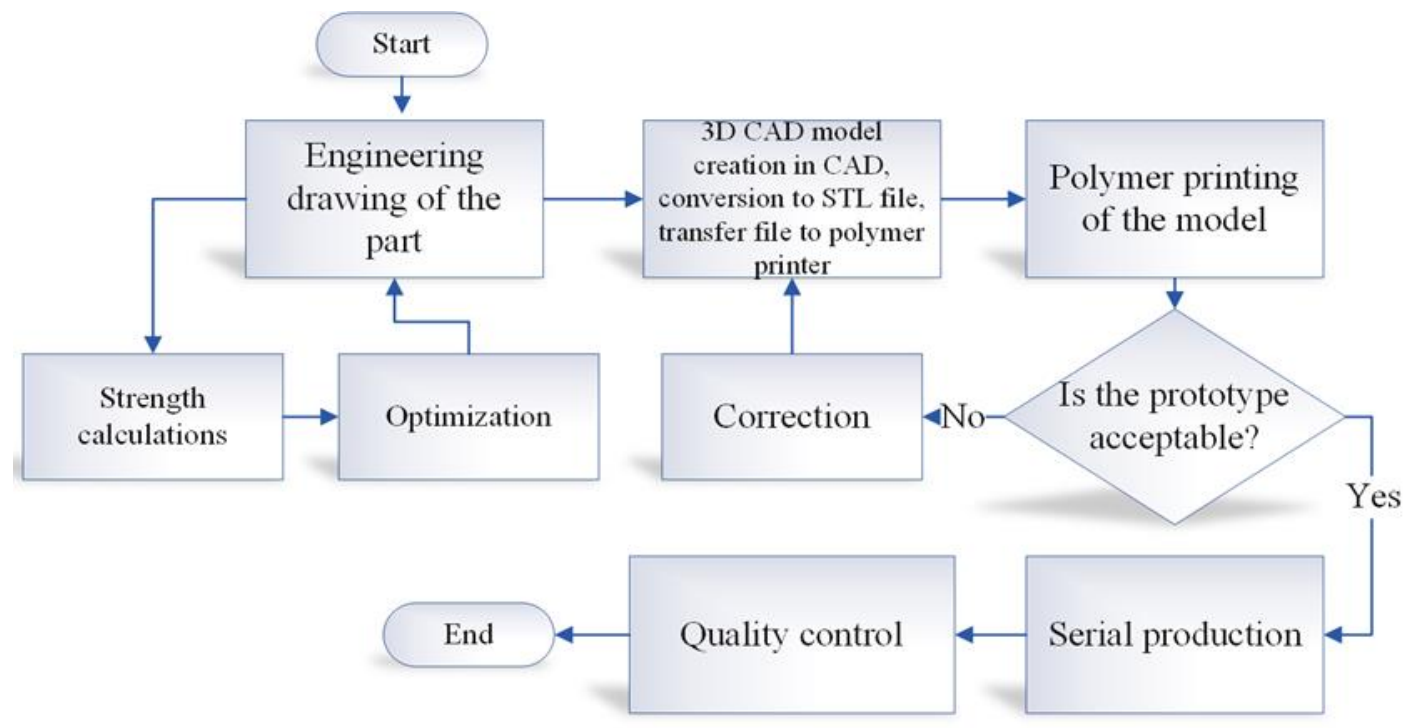

Fig. 2. Process chain for manufacturing of prototypes. 


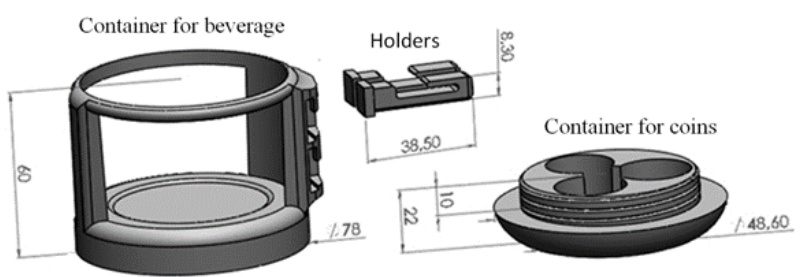

Fig. 3. 3D technical drawing of the holder components: a casing, connector, bottom plate, and $b$-view of finished part.

a)
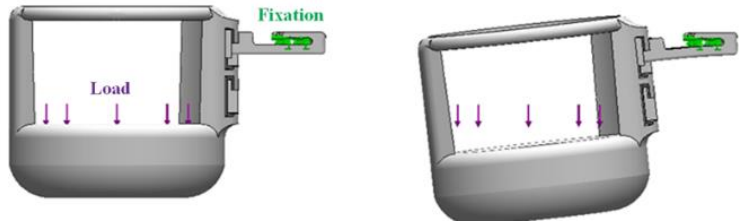

b)

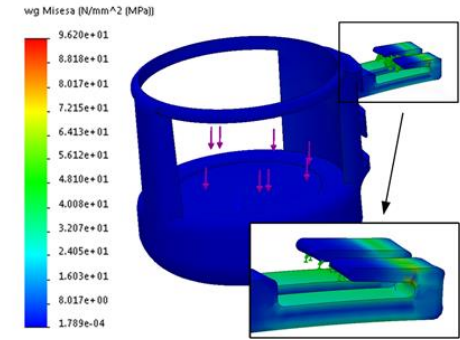

Fig. 4. 3D model for strength simulation before and after loading (a) and calculated equivalent stress distribution under load (b).
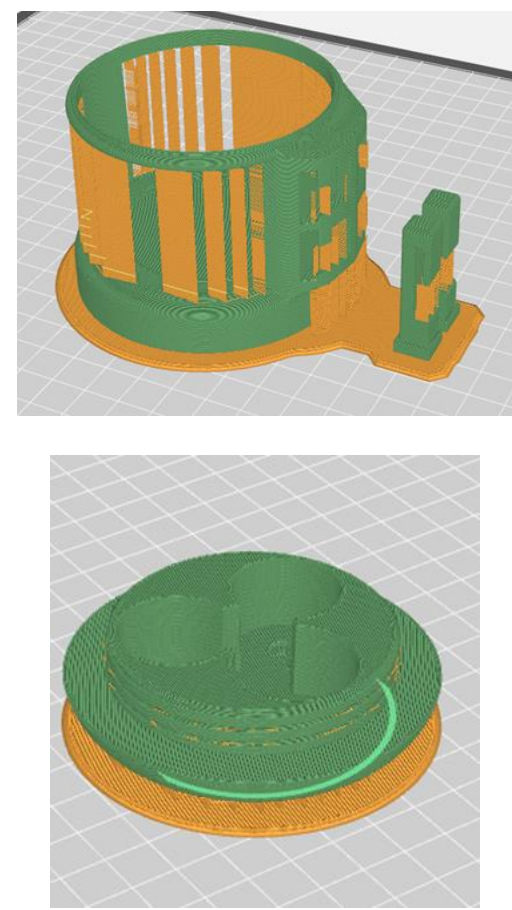

Fig. 5. The STL models generated in the Makerbot Print program with raft and support.

The models was printed from ABS and nylon on a MakerBot Replicator Z18 printer. The printed models after post processing are shown figure 6 .
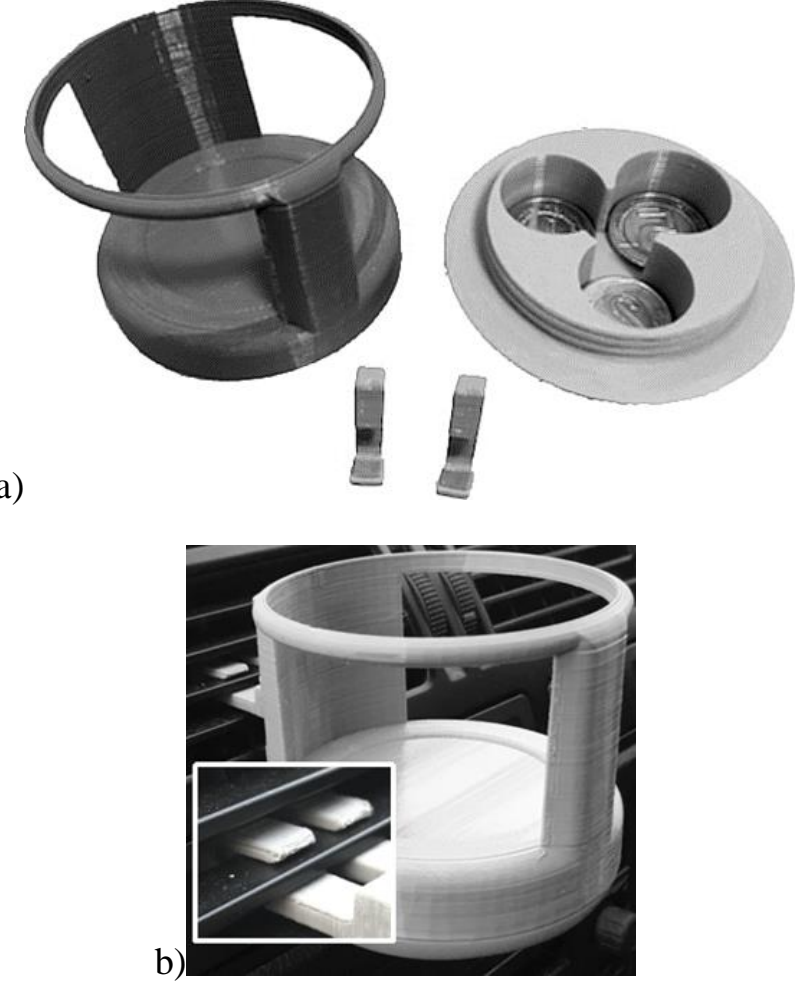

Fig. 6. Component of polymer models printed in stages (a) and the assembled holder on airflow car ventilation (b).

This polymer model is a prototype which can be adapted and tested before individual or serial production by aluminium casting, or Metal Injection Moulding (MIM), or Polymer Injection Moulding (PIM).

\section{ADDITIVE MANUFACTURING ASSISTING THE DESIGN OF CON ROD CLOSED-DIE FORGINGS}

Figure 7 shows a possible additive manufacturing chain involving initial 3D polymer printing of models of the die and preform forging, in every stage of pressing, and the required shape and size of the metal component. This procedure enables verification of their shapes and possible redesign at the polymer model stage. Manufacturing from appropriate metallic material takes place after verification of polymer printed models. Thus a cost saving results.

Stages of designing con rod technology are:

Step 1. A technical drawing of the con rod. Drawing the shape of the forging and preform, by the method of Rebielskij (1965), Lange (1958) and of the die set (Doege \& Behrens, 2010; Wasiunyk, 1975).

The value of the preform diameter was calculated for various cross-sections of forgings taking into account flash. The ideal forging preform is designed 


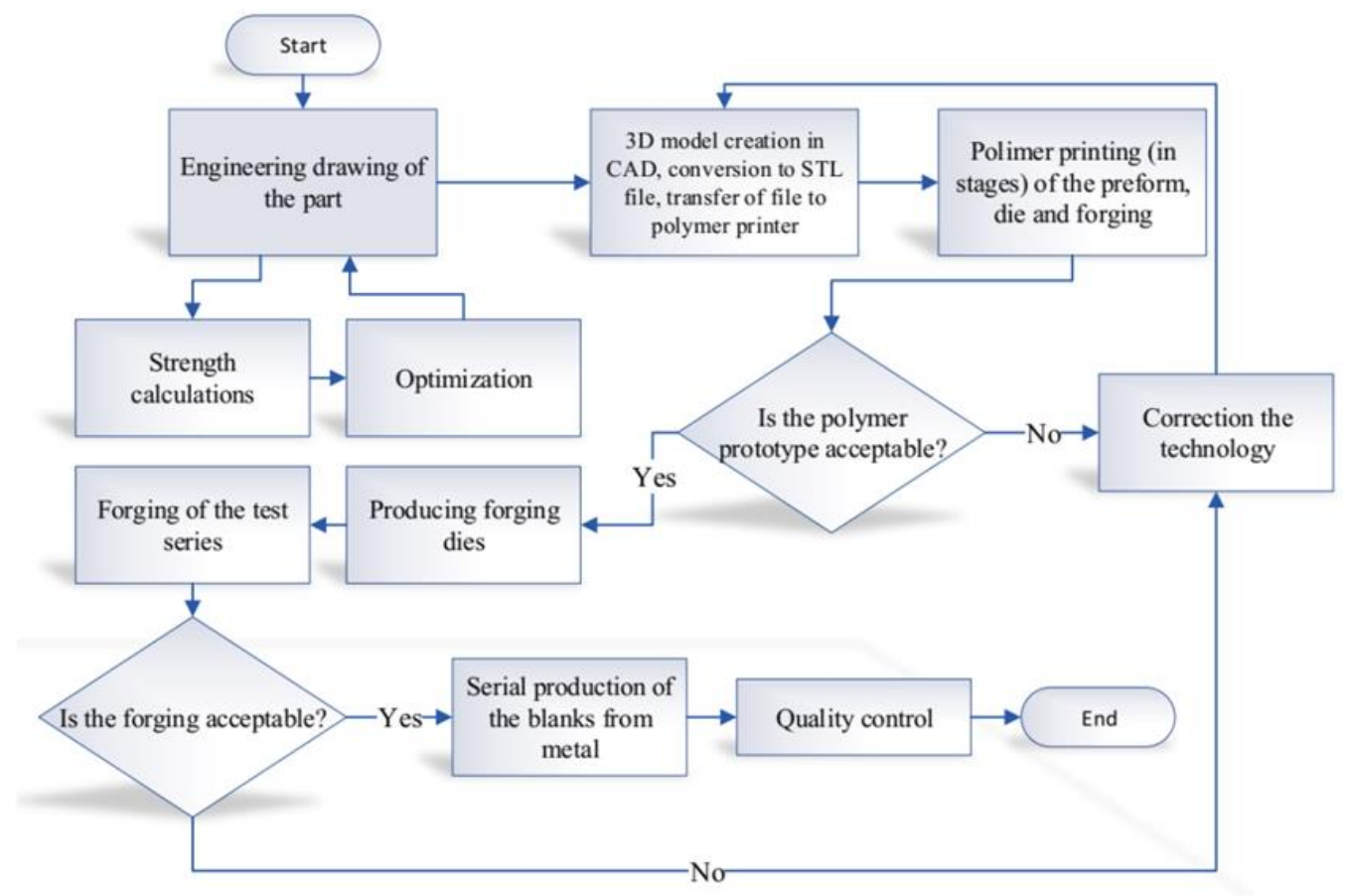

Fig. 7. Process chain for additive manufacturing of products (Szczepanik \& Nikiel, 2019).

from these data (Rebielskij, 1965; Lange, 1958). Preform can be produced by rolling bar stock in specially designed rolls, or by press forging.

Step 2. 3D in creation of preform and die in CAD models for FEM simulation, optimization of the forging process from Rebielskij-type preform using Simufact Forming program for 7022 aluminium alloy.

Step 3. A Conversion to STL files 3D models of the con rod, the preform forging, the forging and the die set.

Step 4. Polymer printing (in stages) of the preform, the die set and the forging.
Step 5. Critical comparison of resultant polymer model forging with dimensional specifications.

Step 6. (if required) Modifications to die and perform models. Repeat of Steps 4 and 5.

Results of modelling are presented below.

Step 1. The technical drawing of the con rod. Drawing the shape of the forging and preform, by the method of Rebielskij (1965), and of the die set (Doege \& Behrens, 2010; Wasiunyk, 1975).

The technical drawing of the con rod and part made from forging is shown in figure 8 and shapes of forging and rolled preform figure 9 .

a)
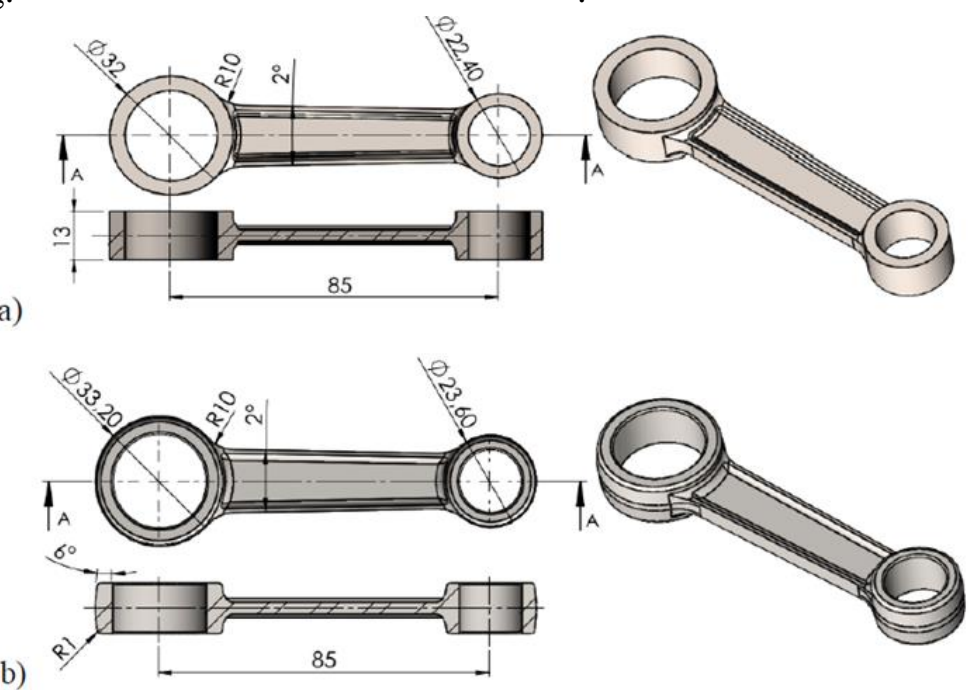

Fig. 8. Technical drawing of: (a) the conrod (10428 $\mathrm{mm} 3$ volume $28.3 \mathrm{~g}$ weight), and (b) the part made from forging (12213 mm3 volume, $33.2 \mathrm{~g}$ weight). 
a)

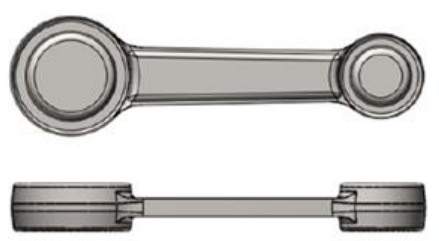

b)

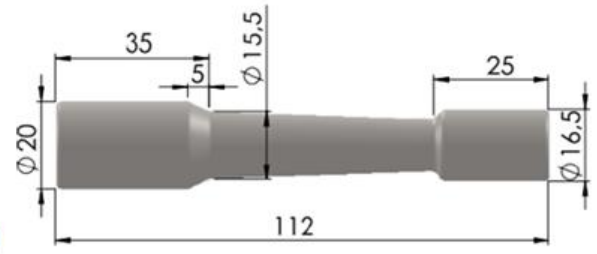

Fig. 9. The shape of the forging with a bottom - $a$ and $b$ - the rolled preform by the method of Rebielskij (1965).

Steps 2 and 6. FEM simulation for optimization of the forging process from Rebielskij -type preform using Simufact Forming program for 7022 aluminium alloy.

Simufact forming FEM simulation, based on MSC Marc solver, was used. The data for simulation were: $250 \mathrm{~mm} / \mathrm{s}$ for the punch speed, material characterization $\mathrm{Al} 7022,460^{\circ} \mathrm{C}$ for the workpiece temperature, $350^{\circ} \mathrm{C}$ for the die temperature and 0.3 for friction coefficient and material characterization of A17022 aluminium alloy at temperature range 360 $440^{\circ} \mathrm{C}$ and strain rate $0.1,1$ and $10 \mathrm{~s}^{-1}$. Geometrical model for the simulation is shown in figure 10 . The first simulation calculation was for Rebielskij original perform. The calculated effective strain and stress, and quality of filling the die shape were not correct.

a)

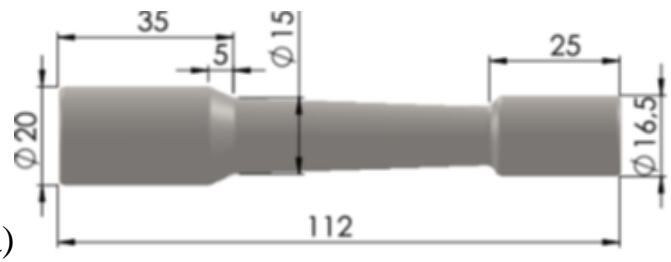

b)

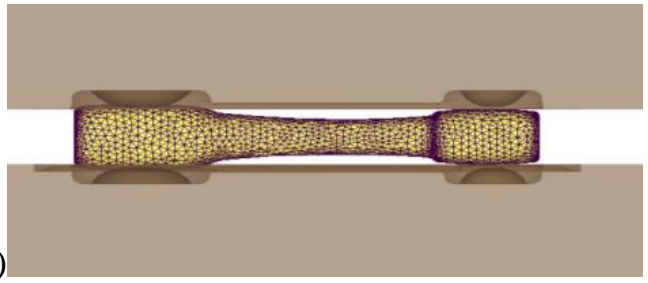

Fig. 10. The shape of the rolled preform by the method of Rebielskij (a) and model for simulation (b).
Correction consisted in changes of dimensions: 35 to $31.5 \mathrm{~mm}, 25$ to $23.5 \mathrm{~mm}$, and diameters 15 to $14.5 \mathrm{~mm}$ and 16.5 to $17 \mathrm{~mm}$. The second simulation was for the corrected perform, giving acceptable quality.

Step 6. Geometrical model for second simulation is shown in figure 11a.The results of the simulation for the corrected preform are shown in figures $11 \mathrm{~b}$ and 11c.

Results of the simulation were analysed, taking into account state of strain and stress, temperature distribution in the material during forming (table 1) and the predicted force, energy and material consumption (table 2).

More homogenous distribution of equivalent strain, stress and temperature appear in the forging after Rebielskji type - preform correction. Material consumption and calculated maximum force and energy are also smaller.

Step 3. A Conversion to STL files 3D models of the con rod, the preform forging, the forging and the die set.

Based on CAD code, the converted models in the STL code were prepared (figure 12) to printing from polymer 3D models in stage and die.

Step 4. Polymer printing (in stages) of the perform, the die set and the forging

The models were printed on a MakerBot Replicator Z18 printer. The printed models are shown figure 13.

Table 1. Calculated range of parameters by simulation.

\begin{tabular}{|c|c|c|c|c|c|c|}
\hline \multirow{2}{*}{ Variant } & \multicolumn{3}{|c|}{ Half time simulation } & \multicolumn{3}{c|}{ End of simulation } \\
\cline { 2 - 7 } & $T,{ }^{\circ} \mathrm{C}$ & $\varepsilon_{e q}$ & $\sigma_{e q}, \mathrm{MPa}$ & $T,{ }^{\circ} \mathrm{C}$ & $\varepsilon_{e q}$ & $\sigma_{e q}, \mathrm{MPa}$ \\
\hline Rebielskij- original & $456-488$ & $0-0.61$ & $46 \div 93$ & $401-478$ & $0.47-2.10$ & $45-182$ \\
\hline Rebielskij after correction & $460-488$ & $0-0.60$ & $37-94$ & $415-477$ & $0.38-1.07$ & $72-173$ \\
\hline
\end{tabular}

Table 2. Material consumption, forging force and energy consumption.

\begin{tabular}{|c|c|c|c|c|}
\hline \multirow{2}{*}{ Variant } & \multicolumn{2}{|c|}{ Mass, kg } & \multicolumn{2}{c|}{ Simulation } \\
\cline { 2 - 5 } & Charge & Forging & Force max, kN & Energy, kJ \\
\hline Rebielskij- original & 0.05 & 0.185 & 0.51 & - \\
\hline Rebielskij after correction & & & & \\
\hline
\end{tabular}


a)
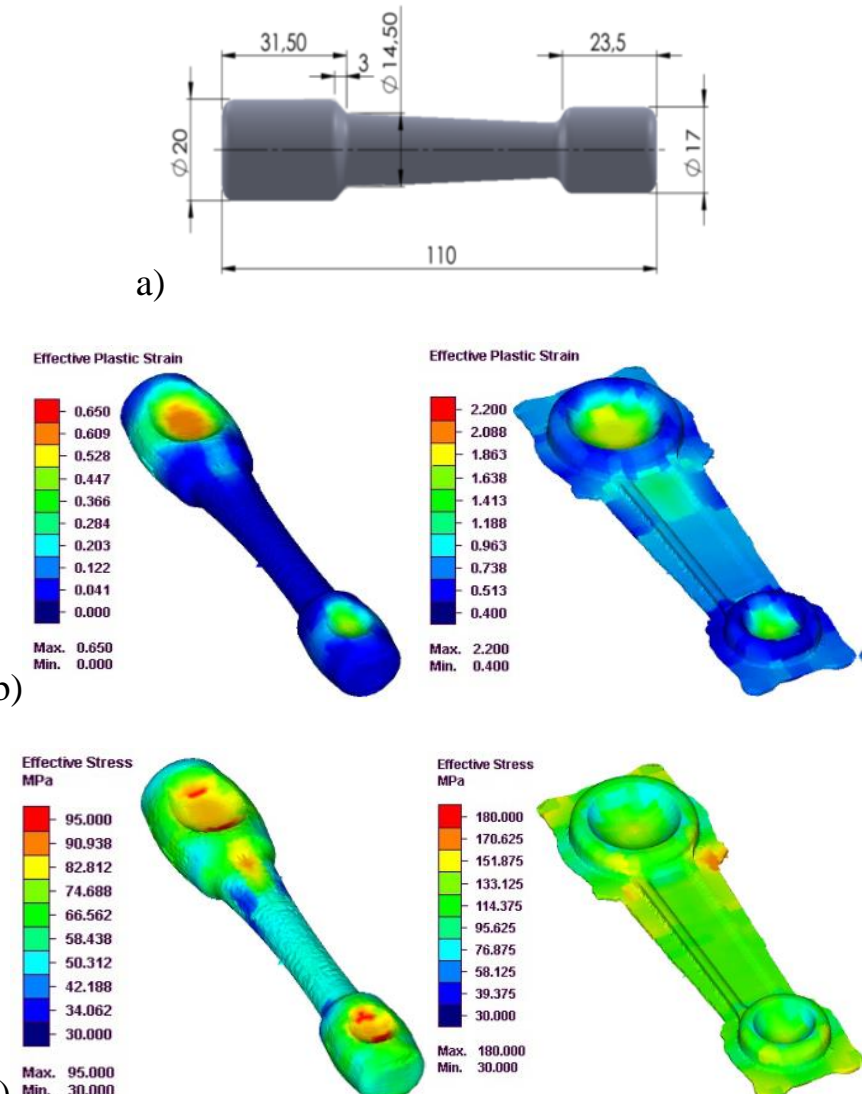

c) ${ }_{\text {Max. }}^{\text {Max. }}$ 35.000

half time of calculaction

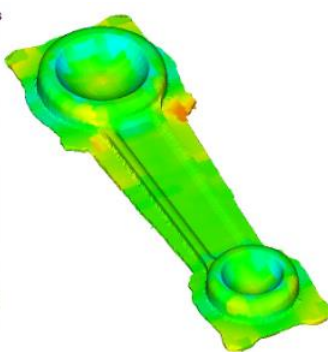

end of calculation

Fig. 11. Simulation results for Rebielskij corrected (Step 6) type preform, model of the perform for the simulation (a) and calculated the effective strain (b) and the effective stress (c).

a)

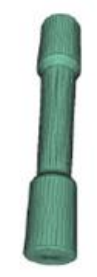

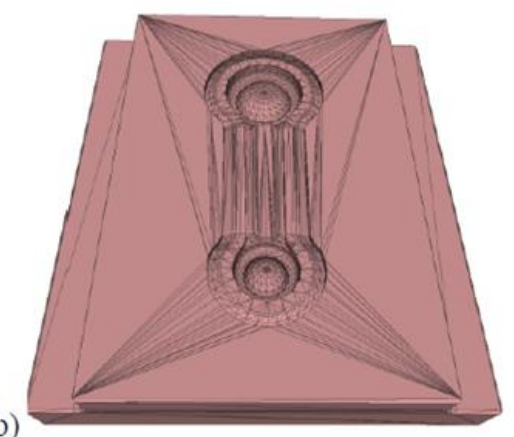

b)

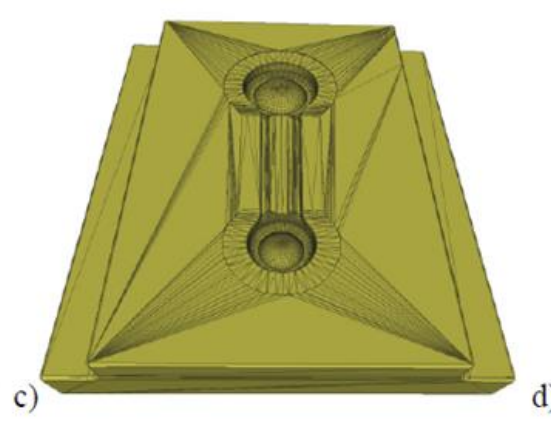

d)

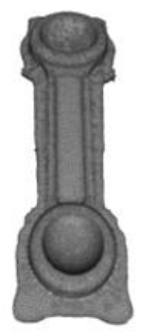

)

Fig. 13. Printed models of con rod (a), rolled perform corrected (b), forging (c) and perform and forging respectively in the die (d,e). 
3D printed polymer models of the perform, the die and the forging during processing give the possibility of verification and visualisation of the planned technological process. These models enable verification at the design stage.

\section{SUMMARY}

The polymer printed models enable verification of the design of the prototype and planned technological process at the design stage.

Simulation assists and verifies the planed technological processes, including analysis of material flow during processing, energy or force needed during forming. The important data needed are: stress, strain, temperature distribution. At this stage it is possible to optimize the processing parameters.

3D printed polymer models are used for a second verification of structural solution. A cheap polymer print material may be used to correct the model structure prior to the final technological solution with an expensive metallic material - without risk.

Applying 3D printing to prototypes in the appropriate metallic materials can lead to tool manufacture and processing in industrial conditions. In this way production costs can be reduced by this new technology.

\section{ACKNOWLEDGMENTS}

The research was financed by the Ministry of Science and Higher Education (AGH - research subsidy no. 16.16.110.663, task 3 ).

\section{REFERENCES}

Doege, E., Behrens, B.A., 2010, Handbuch umformtechnik: grundlagen, technologien, maschinen, Springer-Verlag, Berlin, Heidelberg (in German)

Gibson, D., Rosen, W., Stucker B., 2010, Additive manufacturing technologies. Rapid prototyping to direct digital manufacturing, Springer, New York, Heidelberg, Dordrecht, London.

Hirschvogel Tech Solutions, 2018, Newsletter, https:// www.hirschvogel-tech-solutions.com/ (06.04.2019).

Lange, K., 1958, Gesenkschmieden vom stahl, Springer-Verlag, Berlin, Heidelberg (in German).

Rebielskij, A.W., 1965, Osnovy projektirowanija processov gorjacej objemnoj stampovki (Bases of planning processes of the die forging). Masinostrojenije. Moskva (in Russian).

Schwam, D., Silwal, B., 2017, Applications of additive manufacturing in forging, Final Report, https://www.forging.org/producers-and-suppliers/technology/additive-manufacturing (03.04.2019).
Szczepanik, S., Nikiel, P., 2019, Additive manufacturing assisting the design of closed-die forgings, Materials Science Forum, 949, 7-14

Wasiunyk, P., 1975, Kucie matrycowe (Die forging), Wydawnictwa Naukowo-Techniczne, Warszawa (in Polish).

\section{ZASTOSOWANIE DRUKU 3D DO WSPOMAGANIA WYKONANIA PROTOTYPÓW I PROJEKTOWANIA PROCESU KUCIA MATRYCOWEGO}

\section{Streszczenie}

Prototypowanie i projektowanie kucia matrycowego z zastosowaniem druku 3D składa się z następujących etapów: opracowanie koncepcji i modelu CAD, konwertowanie modeli CAD do formatu STL, definiowanie parametrów druku, drukowanie i obróbka wykańczająca wydruku. Modyfikowanie modeli odbywa się przy założonych kryteriach dotyczących kształtu, stanu naprężenia i odkształcenia oraz rozkładu temperatury. Przedstawiono procedurę wykonania prototypu uchwytu na kubek z dwóch polimerów oraz opracowanie procesu kucia matrycowego odkuwki korbowodu.

Zastosowano metodę Riebielskiego do projektowania procesu kucia matrycowego korbowodu z przedkuwki walcowanej. Opracowano dokumentację CAD wyrobu, przedkuwki, odkuwki oraz matryc do kucia. Poprawność opracowanej technologii weryfikowano z zastosowaniem programu Simufact Forming. Po dokonanych korektach przedkuwki uzyskano spełnienie kryteriów i wykonano w technologii druku 3D model matryc, modele przedkuwki i odkuwki korbowodu. Wykazano, że symulacja jest kluczowa do optymalizowania kształtu wyrobów przy opracowaniu prototypów i technologii kucia.

Received: October 7, 2019 Received in a revised form: November 21, 2019. Accepted: December 30, 2019. 